\title{
Prophetic Education of Guru Sekumpul for Social Studies Education
}

\author{
Ersis Warmansyah Abbas \\ History Education Departement \\ Faculty of Teaching and Education \\ Universitas Lambung Mangkurat \\ Banjarmasin, Indonesia \\ ersis_wa@unlam.ac.id
}

\begin{abstract}
In the effort for practicing Social studies education as a powerful teaching, the concept and practice of innovative education are needed. As the powerful teaching aiming at character building in the frame of good citizenship, social studies education may implement the model of prophetic education of Guru Sekumpul (K. H. Zaini Abdul Ghani). The Prophetic Education of Guru Sekumpul is a concept and practice based on the apostolic education (Rasulullah SAW). Prophetic education of Guru Sekumpul begins with contemplation and reading of confession (syahadah) in the efforts to strengthen belief, to improve devotion, and (by) following Rasulullah as practiced by Guru Sekumpul in the model of dakwah: (1) orally religious proselytizing, (2) behaviorally religious proselytizing, (3) and religious proselytizing through book writing. Implementation of Prophetic Education of Guru Sekumpul in social studies education will result in social studies education as the powerful educational practice because it is meaningful, integrative, value-based, challenging, and active.
\end{abstract}

Keywords - prophetic education, social studies education, and powerful

\section{INTRODUCTION}

Education is a learning process that functions as a character building. The character building is directed in order that the students can make change for the better life through the development of knowledge, attitudes, and skills. Social studies education aims to develop the knowledge, skills, attitudes, and skills based on the values of the society and the nation so that the students become good citizens.

According to National Council of Social Studies [1], "the social studies is a conceived as the subject matter academic disciplines somehow, simplified, adapted, modified, or selected for school instruction. NCSS national standards for social studies teachers are as follows: (1) identify the thematic and discipline content that NCSS believes all prospective social studies teachers-comprehensive social studies, history, geography, civics, government, economics, and psychology-should study, know, and able to teach (2) require the faculty of teacher preparation programs to demonstrate licenses to possess the knowledge, and competence".
Defines social studies education as a simplification or adaptation of the disciplines of the social sciences and humanities as well as basic human activities that are organized and presented in scientific and pedagogical or psychological ways for the educational purposes [2].

There are the various complaints put forward by the various parties on the social studies education. One of those is caused by the fact that the Ministry of Education and Culture of the Republic of Indonesia has not produced teachers of social studies education yet. Learning and teaching of social studies education have been conducted by the teachers of History, Geography, Economics, Civics, Sociology, Anthropology, and so forth. According to Said Hamid Hasan, more or less $60 \%$ of the teachers of social studies education in Indonesia do not have the background in social studies education [3].

On the other side, global perspective on development of Social Studies Education should refer to United Nations Economics and Culture Organization (UNESCO) that is based on four pillars: learning to know, learning to do, learning to be, and learning to live together [4]. Social Studies Education is developed in the frame of powerful Social Studies Education. Powerful Teaching and Learning in the Social Studies constructed by NCSS [5] through "Curriculum Standard for Social Studies Expectation of Excellence" states that teaching and learning in the social studies are powerful:

1. when they are meaningful,

2. when they are integrative,

3. when they are value-based,

4. when they are challenging,

5. When they are active.

In teaching practice in schools in Indonesia, both the concept and practice of social studies education require renewal. Social studies education becomes one of the subjects which make students bored and less interested. This is in contrast to the practice of Sekumpul recitation conducted by Guru Sekumpul (Sekumpul Teacher) (K.H. Muhammad Zaini Abdul Gani).

Illustratively, when the social studies teacher says that next week the teaching and learning process is free because 
there will be a meeting of the Board Teachers, the students will happily respond, even followed by the shouting: Yippee. Contrary to the condition, when Guru Sekumpul says that next week the recitation will be dispensed, the recitation community will be unhappy, even some of them are crying because they imagine they will not get the lesson from Guru Sekumpul. Guru Sekumpul has been successful in presenting a meaningful, integrated, value-based, challenging teaching and learning process, and making the recitation community active in learning process.

\section{METHOD}

This research used qualitative approach. This research is conducted in the place of Sekumpul Religious Recitation in Martapura city. The heterogeneous population was sampled using the techniques of non-probability sampling based on the snowball random sampling and purposive sampling. Data were collected through observation, interview, and documentation. The data were analyzed using the model of [6]: data reduction, data display, and conclusion drawing/verivication.

Data trustworthiness determination [7] was conducted by using the test of the levels of credibility, transferability, dependability, and confirmability. Data credibility test was conducted by lengthening of observation, increasing of perseverance in research, triangulition, discussion to colleages, and memberchek. Transferability test involved external validity showing finding generalization with diversion of empirical events on context similarities. Dependability test was conducted by asking some experts to read and audit the research. Comfirmability test was conducted through focus group discussion (FGD).

\section{RESULT}

\section{A. Prophetic Education of Guru Sekumpul}

Guru Sekumpul Islamic Recitation (K.H. Muhammad Zaini Abdul Ghani) is an education-based religious proselytizing. As an islamic preacher (da'i), Guru Sekumpul resembles religious proselytizing material in the frame of commanding the good and forbidding the unjust behaviors in an effort to build Moslem personalities. In the relation, Guru Sekumpul teaches religious lessons (hikmah) to improve people's quality, their families', the immediate environment, and community based on moral education in order to build good behaviors (akhlaqul karimah). The religious lessons as expressed [8] from Ibn Qoyyim (At Tafsirul Qoyyim) are as follows: "... religious lesson is knowledge of the truth and its practice, the precision in word and its practice. It cannot be achieved except through the understanding of the Qur'an, and deepening the Shari'a law as well as the nature of faith".

Guru Sekumpul builds optimism in human relationships (hablumminannas) and the relationship to Allah (hablumminallah). A Moslem must know himslef, build hospitily silaturrahim to strengthen faith, increase piety, and emulate the Prophet. Words of Allah are practiced in the life of the Prophet.

Guru Sekumpul has very good knowledge about the Qur'an, the Hadits of the Prophet, Islamic law, Islamic history and general knowledge packed for religious proselytizing activities, namely through: religious proselytizing in speech (bil-lisan), religious proselytizing in action (bil-hal), and religious proselytizing in writing Islamic books (bit-tadwin) as an educational model of the Prophet Muhammad (Prophetic Education).

\section{B. Religious proselytizing in speech (bil-lisan)}

Religious recitation or proselytizing is the sharing of knowledge (science) of Islam. Religious recitation or proselytizing in speech (bil-lisan) emphasizes to the individual obligation (fard 'ayn) in relation to Allah, in relation between human beings, and in relation to the nature (environment). Personality of Moslem relies on the Qur'an and Hadits. The Qur'an contains subject matter in which its practice is in word, deed, tahrir, and the wisdom of the Prophet. When the things are in relation to contemporary problems, their references are the Moslem scholars as the heirs of the Prophet. Guru Sekumpul conveys and explains the principles of Islam with emphasis on tauhid (monotheism), fiqih (jurisprudence) and tasuwuf (sufism).

Tauhid is an aqidah (principle) as a statement of the oneness of Allah SWT : Asyhadu an-laa ilaaha illallaah Wa asyhadu anna Muhammadar rasuulullaah is called as syahadah. Belief only to Allah SWT (stating the oneness of Allah) as the God (Rabb) that has planned, created, managed, maintained, and possessed everything. Words of Allah SWT (Q.S. Az-Zumar: 62): "God creates all things and He maintains everything". It is a Powerful Shahada (recognition) to understand the essence, to live it, to unite words with deeds, and to sincerely perform the duty. Implementing shahadah makes someone wholly surrenders to Allah and His Messenger.

Emphasis of religious recitation to tauhid monotheism is in relation to the science of jurisprudence as Islamic law that addresses the law as a regulator of human life. Fiqih discusses ways of worship, relationships among human being, or human relationship to Allah's creation based on the Qur'an and Sunnah. Fiqih discusses syari'ah law and its relationship to everyday human life, worship, and muamalah. There are five rules of Islam :

1. Wajib (compulsory), namely instruction that is obligated to condut.

2. Sunah, namely something suggested.

3. Haram, namely something that is forbidden to conduct.

4. Makruh, namely lighter ban.

5. Mubah, namely something that may be conducted and abandoned.

If there is a difference among the followers of Islam, it is solved by ijtihad. The Qur'an does not contain the detail, for example in the way of prayer. It is stated in the words of Allah (Surah Al-Baqarah: 43) "And perform your prayer (salat), pay your zakat and conduct your rukuk together with those who conduct the rukuk." Many worldly problems, 
from visiting etiquette, war, and politics, up to addressing the local head elections should be addressed by what Allah SWT warns at the end of the verses of the Qur'an, afala taqilun, afala tafakkarun.

The discussion of tauhid and fiqih in Sekumpul's religious recitation are supported with tasawuf. Tasawuf of Islam is meant for improving human's morality in order to gain happiness in both physical and spiritual lives, in the world and the hereafter. Words of Allah (Surat ash-Shura: 20):

"Whoever desires the harvest of the Hereafter - We increase for him in his harvest. And whoever desires the harvest of this world - We give him thereof, but there is not for him in the Hereafter any share".

Life of the Prophet Muhammad is the sufic life. Rasulullah SAW is the example of human 'preparing' the life in the hereafter, fidunnya wal akhirah. Guru Sekumpul takes the road of Sammaniyah thariqah developed by Shaykh Muhammad Ibn 'Abd al-Karim al-Samman alMadani [8]. In his sermons, Guru Sekumpul reads the book of al-Risalat al-Nuraniyyah fi Sharh al-tawassulat alsammâniyyah. Recitation of Guru Sekumpul are : (a) reciting tahlil of la illaha illallah 166 times, (b) ism aljalalah Allah Allah 33 times, (c) hua hua 77 times and (d) reciting prayers 4 times: Allahummaghfir liummati sayyidina Muhammad, Allahummarham ummata sayyidina Muhammad, Allahummajbur ummata sayyidina Muhammad.

Guru Sekumpul promotes Sammaniyah thariqah after studying the various streams of thariqah. From Kiai Falak, Guru Sekumpul received 27 lessons of thariwah, but he chose to teach Sammaniyah thariqah. Therefore, in Religious Recitation of Sekumpul, the recitation of Manaqib and haulan of Sheikh Sheikh Samman Samman have been conducted each year and attended by hundreds of thousands of people. Manaqib recitation of the famous scholar and Maulid Habsy are not only recited at the commemoration of the birth of the Prophet or in the days of batasmiah but these are conducted every day. Guru Sekumpul's orally religious proselytizing is the educational model of the Prophet Muhammad (Prophetic Education).

\section{Behaviorally religious proselytizing}

Behaviorally religious proselytizing is a proselytizing through action (bil-hal). Guru Sekumpul imitates the Prophet contemplating the majesty of Allah to the Cave of Hira by doing khalwat and siyahah, practicing the values of Islam in daily life.

The example can be seen in development of the area of Sekumpul. Guru Sekumpul made vacant and abandoned lots into the center of Ar-Raudhah prayer place like Nabawi mosque of Medina, after "hijrah (moving)" from Keraton Martapura region, as the center of the symbol of Islam. Sekumpul region develops as the economy center supported by the development of shop, store, home store and 'market of Islam'. Individually, Guru Sekumpul develops the business, gives venture capital to others, especially to his followers, trades diamond (diamond rings), builds home- stores, car showrooms, printing, AZ Express Food, AZ Bakery, perfume shop and so with 108 products belonging to company group of Guru Sekumpul, Al-Zahra.

Preaching and business as the 'farm of the worship' enable Guru Sekumpul to possess more than enough treasures. However, he chooses a simple life. Guru Sekumpul's treasures are spent for the wherewithal in the various purposes. Religious sermon community of Sekumpul are supplied drinking water, bread, and books. There are many individuals or institutions that need the funds have been fulfilled by Guru Sekumpul.

Guru Sekumpul is in the ascetic life. Treasure is not used to accumulate wealth, but it is spent for charity to the people in need. Giving is nobler than accepting. For Guru Sekumpul, the treasure acquired through business is not his 'property'. For Guru Sekumpul, the property belongs to Allah and is spent or used for the sake of religious proselytizing. The religious proselytizing practiced by Guru Sekumpul is the educational model of the Prophet Muhammad (Prophetic Education).

\section{Religious proselytizing through writing}

Guru Sekumpul practices religious proselytizing based on the principle of bit-tadwin (through writing) by writing and publishing books and compact dish (CD). The uses of books or CD-s are for establishing the materials presented by Guru Sekumpul for the followers to learn at home or for those who do not attend the recitation. In the proselytizing of Islam there are very well-known words: "Verily, the moslem scholars' ink is better than the blood of the martyrs". The proselytizing through writing does not only deliver good things in order to avoid bad things, but in the perspective of culture it is included in the building of civilization.

The Books of Guru Sekumpul: Risalah Hadits Nur, Kitab Risalah al-Wasilak, Manaqib asy-Syeikh as-Samman, Ar-Risalah an-Nuraniyah fi Syarhi at-Tawassulat asSammaniyah, Nubdzatun fi Manaqib al-Imam al A'zhom al Faqih al-Muqaddam, Risalah Mubarokah, Ar-Risalah fi Aurad al-Mufiidah, 8 al-Imdad fi Auradi Ahlil Widad, and poems in the manuscript form. Guru Sekumpul wrote some beautiful poems in the form of praise to Allah and the Prophet.

The Prophet ordered the Companions to write the Qur'an on the stones, stems of dates, and animal skins. The writing had been done when the Companions have understood the verses of the Qur'an. The proselytizing through writing is the educational model of the Prophetic Education.

\section{CONCLUSIONS}

Indonesia whose society consists of various races, ethnic cultures, nations, and religions should consider the importance of multicultural education implementation. It cannot be denied that diverse Indonesian society is often the cause of the various kinds of conflict. In the context of Indonesia, known as a plurality-rich content, the role of multicultural-based education becomes highly strategic in 
order to manage diversity creatively, so conflicts that arise as a result of transformation and social reform can be managed intelligently and become part of the nation's enlightenment. Multicultural education in Indonesia can only be built through sustainable and integrated efforts. The roles and supports are needed from teachers/faculties, educational institutions, and other education policy makers, especially in the application of curriculum with a multicultural approach. Teachers and educational institutions (schools) need to understand the concept of multicultural education in a global perspective resulting the values contained in this education can be taught as well as practiced in the presence of learners. Therefore, through the development of this multicultural education the learners will understand the lessons more easily and raise their awareness to always behave with humanist, pluralist and democratic attitude.

\section{REFERENCES}

[1] National Council of Social Studies (2000: 62), Retrieved from https://www.socialstudies.org/, 2000

[2] N. Soemantri, Menggagas Pembaharuan Pendidikan IPS, Bandung: PT. Remaja Rosdakarya, 2001.

[3] S.H Hasan dkk, Pengembangan Pendidikan Budaya dan Karakter Bangsa, Jakarta: Kementrian Pendidikan Nasional Badan Penelitian dan Pengembangan Pusat Kurikulum, 2010.

[4] S. Danim, Pengantar Kependidikan, Bandung : Alfabeta, 2010.

[5] NCSS (1994: 162-170) Re trieved from https://www.socialstudies.org/

[6] M. B Miles, AM Huberman, J Saldana, Qualitative data analysis: A sourcebook, Beverly Hills, 1984

[7] J.L Moleong, Metode Penelitian Kualitatif, Bandung : PT. Remaja Rosdakaya, 2009

[8] S. Munzier dan H. Hefni, Metode Dakwah, Rahmad Sentosa, Jakarta, 2003.

[9] Shaykh Muhammad Ibn 'Abd al-Karim al-Samman al-Madani (Team of Al-Zahra, 2006: 356-361 and Mirhan, 2012: 148-158 